\title{
DIGITALIZATION OF INTANGIBLE CULTURAL HERITAGE (ICH) ARCHIVES AS LEGAL PROTECTION OF INTELLECTUAL PROPERTY RIGHTS
}

\author{
Amri Hariri* \\ *Pascasarjaana UIN Sunan Kalijaga Yogyakarta \\ Email: amri.hariri@ump.ac.id \\ (Submitted: 11-07-2021, Revised: 06-11-2021, Accepted: 24-11-2021) \\ DOI: $10.24252 / \mathrm{v} 9 \mathrm{i} 2 \mathrm{a} 7$
}

\begin{abstract}
ABSTRAK: Digitalisasi arsip warisan budaya takbenda menjadi pekerjaan yang sangat penting dilakukan di era digital. Pasalnya arsip sebagai budaya bangsa yang harus terus dilindungi dan dilestarikan agar tidak di klaim oleh pihak asing. Tujuan penelitian ini adalah untuk mengetahui pentingnya arsip WBTB sebagai perlindungan hukum atas HKI. Basic design penelitian ini adalah literature review. Sumber data dalam kajian ini yakni; artikel jurnal ilmiah, buku, dan dokumen dari organisasi terpercaya. Teknik analisis data menggunakan metode analisis isi yang digunakan untuk menganalisis teks dengan objektif dan valid. Hasil penelitian ini menjawab empat isu penting yakni (1) digitalisasi arsip dapat dilakukan dengan merujuk pada kebijakan IFLA; (2) arsip WBTB dapat dimanfaatkan untuk pengajuan HKI dalam bidang kepemilikan komunal; (3) digitalisasi arsip WBTB berperan penting dalam upaya menjaga budaya bangsa, perlindungan hukum, menjaga budaya agar dapat memanfaatkan selanjutnya, keamanan, menyediakan akses publik, memudahkan dalam proses penyimpanan kembali arsip, dan hemat biaya perawatan; (4) perlindungan hukum terhadap WBTB dapat dicapai dalam empat cara yakni melalui melalui hukum adat, di daftarkan menjadi HKI, pencatatan dan penetapan WBTB oleh Kemdibud RI, penetapan ICH UNESCO sebagai wujud representasi pengakuan dunia. Seluruh proses tersebut merupakan tindakan preventif agar tidak terjadi diskriminasi, klaim sepihak dalam rangka mencapai kesejahteraan dan keadilan hukum.
\end{abstract}

Kata kunci: Digitalisasi arsip; hak kekayaan intelektual; kepemilikan komunal; warisan budaya takbenda

ABSTRACT: Digitizing (ICH) archives is an important thing in the digital era. These archives are national cultures that must be protected and preserved and could not be claimed by foreign parties. This study aims to find out the importance of ICH archives as legal protection for IPR. The design of this research is a literature review. The data sources were scientific journal articles, books, and documents from trusted organizations. To analyze the data, the researcher uses the content analysis method to analyze the text objectively and validly. The results of this study answer four important issues, namely (1) digitization archive can be done by referring to IFLA policies; (2) ICH archives can be used for IPR submission in the communal ownership field; (3) digitizing ICH archives have an important role in efforts to maintain the national culture, legal protection, security, providing public access, make the archive re-saving process more manageable, and saving maintenance costs; (4) legal protection of ICH can be achieved in four ways, namely through customary law, registered as IPR, recording, and stipulation of ICH by the Ministry of Education and Culture of the Republic of Indonesia, the stipulation of UNESCO ICH as a representation of world recognition. Those whole processes are a preventive measure to prevent discrimination and unilateral claims to achieve prosperity and legal justice.

Keywords: Archive digitization; communal ownership; intangible cultural heritage; intellectual property rights 


\section{INTRODUCTION}

Indonesia is a rich country, the extraordinary masterpiece of the Creator that can be found in the world. The abundant natural wealth that is priceless, the diversity that is so fascinating, the sustainable value of Indonesia's natural wealth, and cultural diversity are part of the wealth that must be maintained through intellectual property. It aims to protect resources that concern the needs of many people and can be used for the prosperity of the Indonesian.

The challenge of globalization makes people aware that culture needs preservation and innovation to maintain its existence and avoid being forgotten by the times (Syadiyah \& Jumino, 2020). Culture is divided into two parts, tangible cultural and intangible cultural. Tangible cultural are cultural heritages that are material in nature, in the form of cultural heritage objects, cultural heritage buildings, cultural heritage structures, cultural heritage sites, and cultural heritage land and water areas that need to be preserved. It is because they have important values for history, science, religious education, and culture through the determination process (Lestari, 2020). Intangible Cultural Heritage is all actions and thoughts that are tangible in identity, ideology, mythology, and concrete expressions in the form of sound, motion and ideas contained in objects, behaviors, beliefs, and customs in Indonesia. Meanwhile, according to UNESCO, intangible cultural heritage is practices, representations, expressions, knowledge, skills, and creativity that are part of the cultural heritage of an area (UNESCO, 2001). The UNSECO Conference classifies the Intangible Cultural Heritage (ICH) into four, (a) oral traditions of oral expression including language; (b) art performance such as the Acehnese Saman Dance; (c) customs as rites and celebrations; (d) knowledge and behaviors regarding the universe, such as the tradition of whaling on the island of Lembata, NTT.

Archive digitization is an activity of transferring archive media from printed forms to digital forms. The purpose of digitization should also be understood as scanning analog documents into digital format and as a series of activities that produce digital copies available on the Internet or other devices (U.S. NARA, 2016). Digitizing archives is essential to work to do in today's digital era. Archives must be preserved as the nation's cultural treasures because past events documented through archives are legal evidence.

Archives have become one of the important prerequisite documents for recognizing intellectual property rights (IPR) because it has a legal force that can be used as evidence of the existence of cultural heritage in the area. Besides being authentic evidence for past events, it is also important evidence in defending the truth. Borrowing Pramoedya Ananta Toer's term that "the archive will not lie because he cannot argue with himself."

Besides being a living tradition \& memory collective, culture is also vulnerable to being claimed by foreign parties. This is one reason of the foundations for the birth of the UNESCO ICH convention. The government and all elements of Indonesian society must learn from the past in which some foreign parties have claimed the Nation's cultural heritage. For examples claims on Reog Ponorogo culture in 2007, followed in December 2008 claiming the song Rasa Sayange, a Maluku folk song, the Pendet Dance from Bali, the Angklung musical instrument from Sunda, the Tor-Tor dance, and the Gordang Sambilan dance from North Sumatra cannot be separated from unilateral claims from overseas (Akuntono, 2012). The latest case is that Lavanya Sivaji, Miss World Malaysia 2021, was criticized by Indonesian netizens for claiming that Batik came from Malaysia. After reaping the controversy, Lavanya finally apologized publicly on her Instagram account (Nariswari, 2021).

The controversy of the two countries regarding Batik is not a novelty case. It occurred because of the similar culture between the two countries. Indonesian Batik has cultural acculturation that is formed from a long historical value and is considered the most developed in patterns, techniques, and quality of work. The tradition of Batik is not only owned by Indonesia but in Singapore, Thailand, India, China, Sri Lanka, West Africa, and East Turkistan as well (Akhir et al., 2015). From those countries with a batik tradition, only Malaysia uses the name "Batik" 
with the exact spelling and pronunciation as Indonesian Batik, even though the name Batik is an Indonesian cultural identity. Therefore, Indonesian cultures need to get legal protection through IPR and UNESCO ICH recognition. Furthermore, Indonesian cultures are very vulnerable to being recognized by other countries because it has very high economic value (Asri, 2018).

Based on that, this study focuses on four objects of study which are (a) archive digitization policy; (b) understanding the types of communal ownership in IPR; (c) the important role of digitizing ICH archives; (d) legal protection against ICH. The topics mentioned above will be explained further in the results and discussion of this study.

\section{PREVIOUS FINDINGS}

Archive digitization is the process of converting information into a digital format (Azim et al., 2018). Azim defines records as information created, received, and maintained by an organization as evidence. Meanwhile, archives are documents that contain the historical background of a country and organization. Archives contain the primary source documents that have accumulated over the lifetime of an individual or organization and are retained to demonstrate the organization's functioning. Currently, digitization is a new method for record and archives management to store archives or documents as a survival in the future. Digitization can also improve accessibility rapidly and create more ways to present archived results to a broader range of new users.

Zhanna (2020) in her case study highlighted the important role of digitization in the process of preserving intangible cultural heritage by using the example of visualizing samples of Kazakh folk dances. She said that currently, much work is being done in the world to preserve ICH at the initiative of the United Nations by the UNESCO Convention for the Preservation of Intangible Cultural Heritage, which was adopted on October 17th, 2003. This research explains that digitalization is done from folk dance movements according to scripts from choreographers, including Kazakh folk dances found in books on Kazakh folk dance stories and choreographers such as Shara Zhienkulova, Dauren Abirov, Aubakir Ismailov, and topical. According to the researcher, visualization of folk dances in video format is more accessible than folk dances described in choreography textbooks by folk dance stage masters. With the digitization of traditional dances, everyone can access them via the internet and an effort to preserve traditional dances for future generations and as an actualization of modern dance choreographers.

Another research was conducted by Kuswati in 2021 on aspects of digitizing and disseminating ancient manuscripts. The basis of this research uses a literature study approach and comparative research methods. The research results showed that digitization and information dissemination activities had been carried out by the Radya Pustaka Surakarta Museum, the Regional Library, and Archives Agency of South Sulawesi Province, and the Lestari Sastra Foundation. The findings of this research claimed that the Regional Library and Archives Agency of South Sulawesi Province and the Sastra Lestari Foundation have digitized and disseminated, and carried out transliteration so that the public easily reads the disseminated ancient manuscripts.

Historically valuable photos are also important to preserve. Prabowo \& Rukiyah (2020) in their article said that the digitization of photo archives was carried out through several stages; planning, collecting/selecting collections, preparing collections and digitizing equipment, processing digitization, editing, distributing, and storing digitized collections. The digitization carried out by the Indonesian Visual Art Archive has succeeded in preserving and assisting the dissemination of archive collections so that the public can use the archives as a means of education or entertainment.

\section{RESEARCH METHODOLOGY}

This qualitative study approached literature reviews. It described the findings of the data obtained regularly and was well explained so that it can be understood by the readers. After the 
survey paper was done and the data were obtained, it then reads, writes, analyzes, summarizes, and then synthesizes the findings. The pieces of literature as the main sources of data in this study are; scientific journal articles, books, and documents from trusted organizations. Primary data sources in this study include, (a) Digitization of Records and Archives: Issues and Concerns (Azim et al., 2018); (b) Guidelines for Digitization Projects for Collections and Holdings in the Public Domain, Especially Those Held by Libraries and Archives (Mcllwaine et al., 2002); (c) the Convention for the Safeguarding of the Intangible Cultural Heritage (UNESCO, 2003). Secondary data sources are obtained from search results on websites, youtube video content, and other documents from sources that can be trusted and have high credibility.

The literature search strategy is conducted by finding out some print collections and electronic resources that can be accounted for by the credibility of the information. Searching process using the keywords archive digitization, intangible cultural heritage, legal protection, intellectual property rights, and translated into foreign languages to facilitate the search for appropriate literature. The data analysis technique in this study uses content analysis. Content analysis is used to obtain valid reasoning and can be reviewed according to the context (Mirzaqon, 2018).

\section{RESULTS AND FINDINGS ANALYSIS}

\section{Archive Digitization Policy}

According to IFLA, eight policies must be carried out by archives institutions and libraries in digitizing archives (Mcllwaine et al., 2002). Those policies align with UNESCO's Memory of the World Program, which aims to safeguard world cultural heritage, democratize, and increase awareness and the need to preserve the documentary heritage of humanity. The eight IFLA policies that serve as guidelines for digitizing archives are;

a) Selection

Considering the value of the selected material and the importance of its contents, technical feasibility demands such as the physical condition of the archive (fragile, damaged or in poor condition), legal issues, and institutional conditions. The issues involved in selecting materials for digitization will be examined from two perspectives: first, the reasons for digitizing archives to improve access and preservation. Second, the selection criteria are based on the content or based on the request of the institution.

b) Technical Requirements and Implementation

The technical requirements and the implementation are divided into three important elements. There is conversion, quality control, and collection management. These guidelines say that digital images are 'electronic photos' mapped as grid points or image elements-typically used for scanning, compression, storage, and printing. In these criteria, questions arise about the attributes of source documents and image quality to be digitized.

In a technical implementation, it is necessary to have special staff to handle the digitization process. Then, each stage of the digitization must be matched with all components for quality control. Staff should know the scope and important methods in the digitization process and should arrange quality control scanning. Special staff who handle the digitization process must be familiar with spatial resolution, tonal reproduction, color reproduction, noise, and artifacts. So archive digitization requires experts; not just any archivist can do this job. They must already have experience or certification of special skills in the field of archive digitization.

c) Legal Aspect

Institutions that want to start a digitalization project need to be aware from the beginning that every document transferred to the media must look at the copyright aspect and legal position that affects user access to objects that have been digitized. This is important to make media transfer activities carried out by archival institutions meet the legal aspects that apply to every digitized document. In digitizing, it is necessary to pay attention to the authenticity of digital images created and produced following the original archival documents. 
There are four criteria for legal aspects that must consider before digitizing archives; copyright, authenticities such as giving digital signatures and digital seals placed in digital objects, intellectual property management, and legal deposits. Related to the cultural heritage, the role of legal deposits is accommodating laws related to print publications and electronic publications. So that before the digitization process begins, it must be explained to what extent it will be accommodated by law.

d) Budgeting

Building a digital collection is expensive and a lot of resources are needed. Before starting an archive digitization project, some basic planning principles need to be taken into account for projecting design, implementation, and maintenance costs. As a continuing commitment at the policy level, such as recovering the costs incurred during the archive digitization process. Based on those principles, a business model can be designed to license the use of digital materials. For example, with a fair concept, such as offering free internet access to low-resolution images, and paying for access to higher resolution images based on their purpose. So that the archival institution is not only a unit cost center or cost center, but also transforming into a profit center, it is a way to increase profits financially and independently so that it can reduce the cost of the archive digitization process.

e) Human Resources Planning

Upgrading new knowledge and skills about all digital aspects is a must for the archivist. Because when they discuss about digitizing archives, it includes not only technical skills but also skills in making proposals and project management which are applied to the development of technical services so that they can plan archive digitization projects effectively. The successful implementation of digital technology is not a matter of hardware or software, but a matter of access to opportunities, which go far beyond technology.

Human resource development is basically intended to break the digital gap (digital divide). There are three important areas as consideration for human resource planning to prepare reliable archivists, upgrading management, capacity building, and social contracts. Upgrading management includes problem-solving to overcome the problem of interaction in management culture, lack of managerial support, and fear in terms of technological innovation. Capacity building is effectively achieved by forming partnerships and ensuring skills upgrading. Furthermore, the social contract is a basic part that provides all job opportunities for new HR.

f) Web Interfaces Development and Maintenance

According to McIlwaine et al., (2002), the unique nature of digital media provides a visual form of cultural heritage information. So, there are four organizational problems related to the development and maintenance of online information resources namely developing digital content, building a team to develop the Web, producing and managing the Web, and also providing Web-based services. At this point, the role of programmers and IT is very much needed, archive institutions must select human resources who can manage and maintain the Web as a means of publishing digital archives. At this level, an IT staff should be able to understand the principles of electronic archive management to secure access to digital content in the long term and understand the application of metadata standards for indexing digital content.

\section{g) Digital Content Preservation}

Digital technology brings disruptive changes such as archival preservation models from conventional to digital forms. Preservation of digital content provides access in a digital form separating the value of information from the degradation of physical media. In addition, archives that have been digitized into digital form do not require preservation activities as is the case with conventional archives due to poor storage as is the case in tropical and sub-tropical climates. 
The advantage of preserving digital content is seen in the activity of creating and copying the content in many locations without losing the value of the information contained within. In an electronic environment, the location of the physical document is irrelevant, and the remote storage option is a normal feature of the backup procedure. In preserving digital content, it is necessary to pay attention to 6 (six) criteria, namely; challenges, policy development, international standards, non-exclusive models mean that digital archive storage platforms have independence, persistent records management, and trusted digital repository media.

\section{h) Project Management}

In digitization projects, a manager must be able to plan, organize, and manage projects to achieve the vision and mission. A project manager can write a proposal that includes an introduction, vision and mission, assessment, activities, performance indicators, required budget, responsible people, and also the project period. Budget management for the duration of the project, operational costs include equipment, transportation, and services; organizational costs, including management, administration, organizational development; lastly staff, including full-time staff, time staff, contract staff, and consultants.

The project manager ensures that the archive digitization cycle exists across processes and workflows. To achieve the maximum workflow, it is necessary to do 3 (three) things, namely monitoring the quality control program, documenting project progress that is reported according to the set time intervals, and establishing a system that can track projects and record all workflows in one database.

\section{Understanding the Types of Communal Ownership in IPR}

In the official Youtube channel of the Directorate General of Mico and Medium Industries of the Ministry of Industry, it is stated that intellectual property rights are rights that arise from the results of thought processes that produce a product or process that is useful for humans (Ditjen IKMA Kemenperin RI, 2020). Functionally, IPR is the right to enjoy intellectual creativity economically, which includes economic benefits derived from the use of an IPR product. Intellectual Property Rights are used to protect original products to avoid counterfeiting, piracy, and foreign claims. Figure 1 chart of IPR ownership quoted from the Modul Kekayaan Intelektual: Bidang Kekayaan Intelektual Komunal (DJKI Kemkumham RI, 2019).

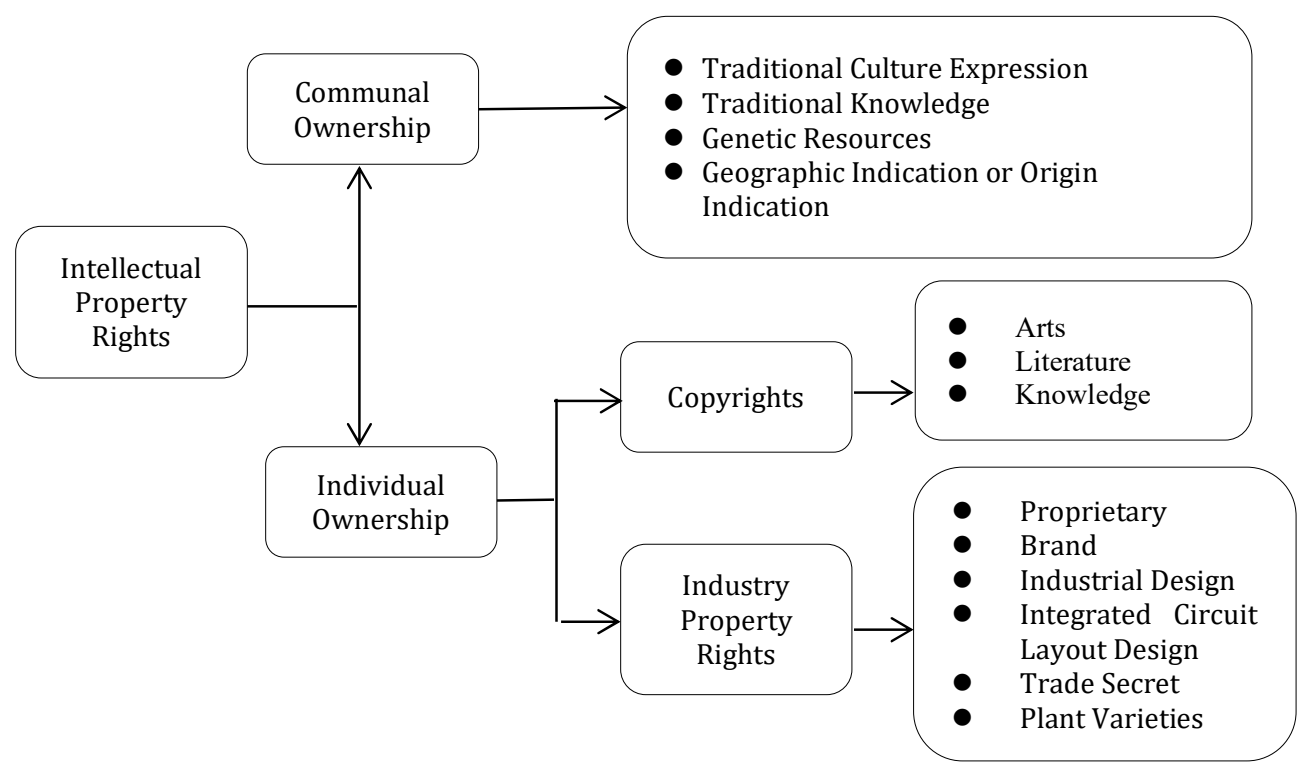

Figure 1: Intellectual Property Rights ownership chart

It figured that the IPR does not only protect personal ownership but also accommodate communal ownership. Communal ownership is intellectual property rights owned by a group of 
people who live in a place permanently. Communal ownership includes; traditional cultural expressions, traditional knowledge, genetic resources, and geographical indications/indications of origin. Thus, IPR in communal ownership protects cultural and communal rights. In this case the author does not agree with Susanti et al., (2019) who said that intellectual property rights only accommodate and protect individual moral and economic rights, considering that the original creator's traditional cultural expressions cannot be traced to who the first creator was.

ICH as part of traditional cultural expressions can be registered as IPR through communal ownership rights because the culture is owned by a community, citizens, or group that becomes the identity of a community. According to Oktaviani in Ditjen IKMA Kemenperin RI (2020) the types of communal ownership or communal intellectual property are:

a) Expressions of Traditional Culture

Are all forms of copyrighted works, whether in the form of objects or not, or a combination of both, which shows the existence of a traditional culture that is held communally and across generations. Examples of traditional cultural expressions are the Pendet dance, the Ngaben ceremony from Bali, Mendoan from Banyumas, the Sundanese angklung, batik, and so on.

The case of Batik Pekalongan which was registered to the Director-General of Intellectual Property Rights at least became a reminder of how important archives are to support documents for IPR submissions. There was 98 Batik Pekalongan registered by HKI in 2004, which were registered by the Department of Industry and Trade of Pekalongan. From 98 batik patterns registered, only 10 were accepted as national cultural heritage, others were rejected because supporting documents did the requirements (Syadiyah \& Jumino, 2020).

b) Traditional Knowledge

This knowledge is defined as an intellectual work in the field of knowledge and technology that conveys elements of the characteristics of the traditional heritage produced, developed and maintained by a particular community or society. For example, the process of making herbal medicine, the process of making woven fabrics, and the Subak system in Bali which regulates the irrigation system/irrigation of rice fields traditionally which is philosophically the meaning of Tri Hita Karana.

\section{c) Genetic Resources}

Genetic resources include a plant or plant, animal or animal, micro-organisms/micro-organisms, or other parts of them that are real and have potential value. Especially, it means that it has uses and benefits in human life like herbal plants that become herbal medicine, such as; Ginger, Black Orchid, and Padang Yogurt.

d) Indication of Geographic Potential

The geographic potential is the original location of an area that has geographical factors, natural factors, or the combination of both that become the main factors for producing items or products. Moreover, if the two factors have a reputation, certain quality characteristics of the goods or products produced have the potential to be protected with geographical indications. Examples of geographical indications are Aloe Vera Pontianak, Malang Apple from East Java, Passion Fruit from North Sumatra, and Aceh Rambutan from Aceh.

\section{The Importance of Digitizing ICH}

In the nowadays digital era, the process of digitizing archives is very urgent, considering that Indonesia has a variety of cultures that must be protected and preserved. With the digitization of archives, the continuing value of the archive will still exist and be preserved. Archives are important documents as authentic evidence, so a culture without supporting archival documents will be very difficult to get world recognition.

We all realize that our citizens still lack awareness of the importance of caring for and preserving archives. The impact is on the very limited number of ICH that is registered in 
UNESCO. In the period 2008 to 2021 alone there are only 12 ICH registered in UNESCO. This number is still very small compared to the number of Indonesian cultures recorded at 10,701. Furthermore, only 1,239 were successfully determined by the Directorate of Cultural Heritage and Diplomacy of the Ministry of Education and Culture both in the category of heritage sites, nature reserves, and ICH.

The data mentioned above proves that Indonesian awareness in storing archival documents is extremely poor. In fact, registering cultural heritage to the Ministry of Education and Culture is a form of preservation carried out by the state as the first step to be registered to ICH UNESCO as a world cultural heritage. Indeed, this is not easy, it took many years to be recognized by UNESCO, for example, Balinese culture in the form of the Subak Landscape took 12 years to be approved by UNESCO as Indonesian cultural wealth in the category of natural heritage. The following is the role of archive digitization in the process of registering the nation's cultural heritage both at the national and international levels, namely;
a) Fulfill national and international obligations to preserve the nation's culture
b) As an effort to provide legal protection for the nation's cultural heritage
c) Protect the culture sustainability so that it can be used by the next generation
d) Provide security for digitized materials
e) Provide archives to be accessed by the public quickly and efficiently
f) Facilitate archive retrieval
g) Guarantee the authenticity, reliability, usability, and integrity of digital copies
h) Save maintenance and preservation costs

The table below is the list of Indonesian Culture that has been officially registered by UNESCO as ICH of the world.

Tabel 1. ICH from Indonesia registered in UNESCO

\begin{tabular}{|c|c|c|c|}
\hline No & Date of ICH & No. ICH & Name of ICH \\
\hline 1. & $04 / 11 / 2008$ & 00063 & Indonesian Puppet SHow \\
\hline 2. & $04 / 11 / 2008$ & 00112 & The Indonesian Kris \\
\hline 3. & $30 / 09 / 2009$ & 00170 & Indonesian Batik \\
\hline 4. & $01 / 10 / 2009$ & 00318 & $\begin{array}{l}\text { Education and training of Indonesian batik as } \\
\text { an intangible cultural heritage for elementary, } \\
\text { middle, and high school students }\end{array}$ \\
\hline 5. & $16 / 11 / 2010$ & 00393 & Indonesian Angklung \\
\hline 6. & $24 / 11 / 2011$ & 00509 & Saman Dance \\
\hline 7. & $04 / 12 / 2012$ & 00619 & $\begin{array}{l}\text { Noken multifunction knotted or woven bag, } \\
\text { handcraft of the people of Papua }\end{array}$ \\
\hline 8. & $02 / 12 / 2015$ & 00617 & Three Genres of Traditional Dance in Bali \\
\hline 9. & $07 / 12 / 2017$ & 01197 & $\begin{array}{l}\text { Pinisi, the Art of Shipbuilding in South } \\
\text { Sulawesi }\end{array}$ \\
\hline 10. & - & - & Pantun, Malay Oral Tradition \\
\hline 11. & $12 / 12 / 2019$ & - & Traditions of Pencak Silat \\
\hline 12. & - & - & Indonesian Gamelan \\
\hline
\end{tabular}

Sumber: https://warisanbudaya.kemdikbud.go.id/?ichunesco 
The culture that has been recognized by UNESCO is certainly a representation of the world's recognition of the culture of the Indonesian people. The world community will automatically pay attention to Indonesia if there is a conflict of claims over the culture, it will indirectly increase Indonesia's positive image in the eyes of the world.

\section{Legal Protection of ICH}

Intangible cultural heritage is implicitly mentioned in traditional cultural expressions as one that is protected in the Copyright Act (Susanti et al., 2019). Under the law, the state is given the authority to hold the copyright to traditional cultural expressions. Legal protection aims to protect the rights of the nation's cultural heritage to achieve prosperity and legal justice in the eyes of the law. According to legal expert Philipus Hardjo, legal protection consists of two aspects, namely, first, preventive legal protection emphasizes that before a government decision is made, people are allowed to submit their opinions to prevent disputes from occurring. Second, defensive legal protection, so the state provides legal guarantees to all parties (legal subjects) to be able to execute their legal rights and interests (Harjon, 1987). The right to legal protection does not only talk about issues in legal disputes, more than that as an effort to prevent natural phenomena such as tsunamis, fires, liquefaction landslides, and so on.

Several conventions and legal basis for ICH provide legal protection for ICH, both on a national and international scale, namely;

a) UNESCO Convention 2003 concerning the safeguarding of the intangible cultural heritage

b) Law Number 28 of 2014 concerning Copyrights

c) Law Number 5 of 2017 concerning the Advancement of Culture

d) Regulation of the President of the Republic of Indonesia Number 78 of 2007 concerning the ratification of the Convention for the Safeguarding of Intangible Cultural Heritage (Convention for the protection of ICH)

e) Regulation of the Minister of Education and Culture Number 106 of 2013 concerning Indonesian ICH

In practical terms, legal protection for ICH is the joint responsibility of all elements of society together with the local government and the central government. The legal protections provided by the state is to identify and make an inventory of ICH in the territory of Indonesia.

The role of the state in the legal protection of ICH including recording, stipulating, and nominating has been carried out by the Directorate of Cultural Heritage and Diplomacy under the Directorate General of Culture of the Ministry of Education and Culture. The recording was carried out by the Cultural Values Preservation Center (BNPB) which was divided into 11 locations and working areas, namely BNPB Aceh, BNPB West Sumatra, BNPB West Java, BNPB DIY, BNPB West Kalimantan, BNPB Bali, BNPB South Sulawesi, BNPB North Sulawesi, BNPB Maluku, Riau Islands BNPB and Papua BNPB. BNPB has the main task of carrying out conservation and one of its functions is to carry out the protection of tradition on aspects of tradition, belief, art, film, and history in its working area. The next right of legal protection is to propose the determination of ICH to the central government which is carried out by the regional government together with the indigenous community as the responsible party. The next step is to make a nomination to UNESCO which is carried out by the local government together with the indigenous community to the Directorate of Cultural Heritage and Diplomacy of the Ministry of Education and Culture so that it is registered in UNESCO's ICH as a form of world recognition of Indonesian culture.

In addition to legal protection through IPR, there is protection that is carried out outside IPR or special protection (sui generis), namely protection through customary law because it contains social norms that are generally obeyed and obeyed by the community (Susanti et al., 2019). 


\section{DISCUSSION}

Archive digitization is an inevitable part of technological development. Digitization simply has an impact on decreasing the usability of original documents due to the preservation of material content by creating substitutes for conventional archives that can be accessed digitally (Alcoholics Anonymous World Services, Inc., n.d.). This is very reasonable because the original documents that have been digitized will be stored in the archival institution that houses them. Conventional archives that are not often exposed to human hands will be better protected because they are protected from acids that can damage the quality of the archive.

The role of digitizing ICH archives as an effort to protect IPR has a huge impact on the cultural identity of a community. ICH archives that have been digitized properly are certainly a very important asset for the community that preserves the culture to submit it to UNESCO as a world cultural heritage.

Until now, there are still many types of communal intellectual property in Indonesia that have not been properly inventoried and documented by the government and there are still many that have not been designated as UNESCO intangible cultural heritage. For this reason, it is important to digitize archives to strengthen sovereignty and legal proof of ownership. The registered culture will strengthen the sovereignty of communal intellectual property as well as become the branding of the Indonesian nation in the eyes of the world. The significant impacts of digitizing ICH archives that have received legal protection for IPR include;

a) IPR certificates are important archives that have legal legality.

b) IPR archives stored in digital format are easy to retrieve.

c) IPR archives that have been transferred to digital media are protected from natural disasters, fires, floods, and paper damage caused by insects.

d) The Intellectual Property Rights Archive becomes a transfer of values for the next generation, thereby minimizing the negative impact on the sustainability of the culture.

It takes a lot of work to convert all paper-based notes into digital form. Institutions also need to prepare the costs because it requires special skills and requires regular training of archivists. However, digitization can also damage archives if it cannot be managed properly because technology is always changing rapidly (Azim et al., 2018). Another consideration when starting to digitize all archives, they also need to create new policies to secure data because the information is more easily leaked when the system is accessible to everyone. So that from this policy it can be known the risks that will be faced and can make preparations early on to minimize risks that arise in the future.

An important emphasis in digitizing ICH archives is on legal protection. We know that research that focuses on digitizing ICH archives in the perspective of legal protection is still rarely appointed as an object of research, even though it is still very "sexy" to be studied. On the other hand, many intangible cultures have lost their historical roots because of the lack of people who care about any documents that explain the journey of a culture that becomes the identity of a community. Without archival documents, it will be very difficult to obtain legal protection in a formal juridical manner. So the archive documents that exist in each individual or group need to be accommodated then recorded and submitted to the archival institution in each region/region for media transfer.

Digitization activities by archival institutions must cooperate with DJKI Indonesian Ministry of Law and Human Rights, Preservation of Cultural Values Center of the Ministry of Education and Culture, and community entities that own and preserve intangible culture. For this reason, digitizing ICH archives is carried out in collaborative work, in order to minimize the preservation of negative risks caused in the future such as misuse, erasure of culture, misappropriation, and claims. 


\section{CONCLUSION}

From the results of the discussion, it can be concluded that archive digitization has a very strategic role in maintaining ICH. so that the Indonesian nation becomes a great nation through its culture. The archive digitization policy guide issued by IFLA needs to be a mandatory reference for archives and libraries. The digitization of ICH archives has a role that cannot be underestimated either by the state or the general public because it has a central role in gaining recognition at the national and international levels. The role of all elements of society together with the local government, and the central government is very important in carrying out legal protection against ICH. Legal protection can be carried out according to formal juridical or through customary law that was born from the habits of the community.

Communal ownership in IPR is divided into several types, namely; traditional cultural expressions, traditional knowledge, genetic resources, and geographical indications/indications of origin. IPR protects not only personal property but also communal property. Digitizing archives is not just changing storage media from conventional to digital forms but more than that so that documented cultural values can continue to be sustainable throughout time.

The roles of digitizing the ICH archives are categorized as a media for storing documents of the nation's cultural treasures, legal protection, preservation and security, easy access, free of maintenance and preservation costs. Legal protection for ICH, aims to defend cultural rights owned by a group from parties who claim cultural heritage unilaterally. ICH can be protected both by customary law and by laws, government regulations, and UNESCO ICH conventions.

It is needed to have good cooperation between the National Archives of the Republic of Indonesia with DJKI Indonesian Ministry of Law and Human Rights and the Center for the Preservation of Cultural Values of the Ministry of Education and Culture in providing legal protection for intangible cultural heritage in every archive digitization process. In addition to collaborating with government institutions, you can also form partnerships with private and community institutions to participate as contributors in each region as an effort to encourage a culture of digitizing archives in the community. Furthermore, the archive institution acts as a verification party of all the archives collected.

The legal aspects of the ICH archives must be considered by archival institutions and libraries before carrying out media transfer activities. Furthermore, archival institutions as a place to digitize archives must be protected by law considering that archival institutions usually do not hold the copyright to the original work. The collaboration between the government and private institutions mentioned above needs to be done seriously and consistently so that the legal protection of intellectual property rights is correctly applied.

\section{REFERENCES}

Akhir, N. H. M., Ismail, N. W., Said, R., \& Kaliappan, S. R. A. (2015). Traditional Craftsmanship: The Origin, Culture, and Challenges of Batik Industry in Malaysia. In R. Omar, H. Bahrom, \& G. de Mello (Eds.), Islamic perspectives relating to business, arts, culture and communication (pp. 229-237). Springer. https://doi.org/10.1007/978-981-287-429$0 \_22$

Akuntono, I. (2012). Dalam 5 Tahun, Malaysia 7 Kali Klaim Budaya Indonesia. https://edukasi.kompas.com/read/2012/06/19/1747119/ Edukasi News

Alcoholics Anonymous World Services, Inc. (n.d.). Digitizing Archival Material Guidelines. https://www.aa.org/assets/en_US/en_digitizinrarchivalmatguideline.pdf

Asri, D. P. B. (2018). Perlindungan Hukum Terhadap Kebudayaan Melalui World Heritage Centre UNESCO. Jurnal Hukum Ius Quia Iustum, 25(2), 256-276. https://doi.org/10.20885/iustum.vol25.iss2.art3 
Azim, N., Mat Yatin, S. F., Jensonray, R., \& Ayub Mansor, S. (2018). Digitization of Records and Archives: Issues and Concerns. International Journal of Academic Research in Business and Social Sciences, 8. https://doi.org/10.6007/IJARBSS/v8-i9/4582

Ditjen IKMA Kemenperin RI. (2020). Hak Kekayaan Intelektual 2. https://www.youtube.com/watch?v=PzSlL-JcqLM\&t=17s

DJKI Kemkumham RI. (2019). Modul Kekayaan Intelektual: Bidang Kekayaan Intelektual Komunal. Direktorat Jenderal Kekayaan Intelaktual Kemkumham.

Harjon, P. M. (1987). Perlindungan Hukum Bagi Rakyat di Indonesia: Sebuah studi tentang prinsip-prinsipnya, penanganannya oleh pengadilan dalam lingkungan peradilan umum dan pembentukan peradilan adminstrasi negara. PT Bina Ilmu.

Kuswati, S. N. (2021). Kegiatan Digitalisasi Naskah Kuno Sebagai Upaya Diseminasi Informasi. LIBRIA, $\quad$ 13(1), $\quad$ Article $1 . \quad 10$ https://jurnal.arraniry.ac.id/index.php/libria/article/view/10971

Lestari, T. (2020). Apa Itu Warisan Budaya Takbenda? https://www.youtube.com/watch?v=imGbGpKY2PA\&t=121s

Mcllwaine, J., Comment, J.-M., Wolf, C. de, Peters, D., Justrell, B., Varlamoff, M.-T., \& Koopman, S. (2002). Guidelines for Digitization Projects for Collections and Holdings in the Public Domain, Particularly Those Held by Libraries and Archives. IFLA. https://repository.ifla.org/handle/123456789/697

Mirzaqon, A. (2018). Studi Kepustakaan Mengenai Landasan Teori dan Praktik Konseling Expressive Writing. Jurnal BK UNESA, 8(1), Article 1. https://jurnalmahasiswa.unesa.ac.id/index.php/jurnal-bk-unesa/article/view/22037

Nariswari, S. L. (2021, October 22). Kronologi Miss World 2021 Malaysia Klaim Batik, Warganet Meradang Halaman all. Kompas.com. https://lifestyle.kompas.com/read/2021/10/22/114000320/kronologi-miss-world2021-malaysia-klaim-batik-warganet-meradang

Prabowo, A. B., \& Rukiyah, R. (2020). Digitalisasi Arsip Foto Indonesian Visual Art Archive Dalam Rangka Melestarikan Arsip Foto di Indonesian Visual Art Archive Yogyakarta. Jurnal Ilmu Perpustakaan, 8(2), 71-80.

Susanti, D. I., Sudhiarsa, R. I. M., \& Susrijani, R. (2019). Ekspresi Budaya Tradisional dan Hak Kekayaan Intelektual. Dioma Malang.

Syadiyah, T. N., \& Jumino, J. (2020). Arsip Sebagai Dokumen Pendukung Untuk Pengajuan Hak Kekayaan Intelektual Batik Pekalongan. Jurnal Ilmu Perpustakaan, 8(2), 189-198.

UNESCO. (2001). International Round Table: Intangible Cultural Heritage, Working Definitions. Meetings on Intangible Cultural Heritage (Co-)Organized by UNESCO. https://ich.unesco.org/en/events?meeting_id=00057

UNESCO. (2003). Convention for the Safeguarding of the Intangible Cultural Heritage. https://ich.unesco.org/doc/src/01852-EN.pdf

U.S. NARA. (2016, August 15). Strategy for Digitizing Archival Materials. The U.S. National Archives and Records Administration. https://www.archives.gov/digitization/strategy.html

Zhanna, R. (2020). Digitization of Intangible Cultural Heritage as a method to save and actualize it on the example of Kazakh folk dance. Proceedings of the 6th International Conference on Engineering \& MIS 2020, 1-7. https://doi.org/10.1145/3410352.3410748 